\title{
POLA - POLA PEMANFAATAN TROTOAR OLEH PEDAGANG KAKI LIMA DI JALAN MANGGA BESAR - JAKARTA
}

\author{
Freddy Kurniawan ${ }^{1}$ \\ ${ }^{1}$ Program Magister Teknik Perencanaan Wilayah dan Kota, Universitas Tarumanagara \\ Email: freddykurniawan93@gmail.com
}

Masuk: 22-01-2019, revisi: 14-08-2019, diterima untuk diterbitkan: 14-08-2019

\begin{abstract}
ABSTRAK
Penelitian ini bertujuan untuk mengetahui pola-pola pedagang kaki lima di Jalan Mangga Besar. Jalan Mangga Besar yang identik dengan hiburan malam dan wisata kulinernya membuat pedagang kaki lima betah untuk berdagang di lokasi tersebut. Pedagang kaki lima tersebut memiliki pola-pola dalam berdagang. Terdapat pedagang yang berdagang secara menetap dan juga setengah menetap. Secara legalitas, terdapat pedagang kaki lima yang non binaan dan juga binaan. Keberadaan pedagang kaki lima binaan ini diatur waktu dan lokasi berdagangnya oleh pemerintah. Pedagang kaki lima non binaan biasanya hanya ijin atau sewa secara tidak sah kepada juru parkir sekitar. Peneliti langsung datang ke lapangan untuk melihat situasi lapangan dan melakukan sesi wawancara kepada beberapa pedagang kaki lima di Jalan Mangga Besar dan pihak kelurahan setempat. Pedagang kaki lima non binaan ini memanfaatkan trotoar dan bahu jalan untuk lokasi berdagang mereka, dan juga menimbulkan kemacetan. Sehingga dibutuhkan desain penempatan pedagang kaki lima non binaan. Sehingga keberadaan pedagang kaki lima non binaan di Jalan Mangga Besar tidak mengganggu akses pejalan kaki yang ingin menggunakan trotoar.
\end{abstract}

Kata Kunci: Pedagang kaki lima; Pola-Pola Berdagang; Mangga Besar; Trotoar; Desain

\begin{abstract}
This study aims to determine the patterns of street vendors on Jalan Mangga Besar. Jalan Mangga Besar, which is synonymous with nightlife and culinary tourism, makes street vendors feel comfortable to trade at this location. These street vendors have patterns in trading. There are traders who trade permanently and also half settled. Legally, there are non-fostered and non-assisted street vendors. The existence of these fostered street vendors is regulated by the government at the time and location of trading. Non-trained street vendors are usually only licensed or illegally rented to the parking attendants around. Researchers immediately came to the field to see the field situation and conducted interview sessions with several street vendors on Jalan Mangga Besar and the local kelurahans. These non-assisted street vendors utilize sidewalks and shoulders for their trading locations, and also cause congestion. So it takes the design of placement of non-fostered street vendors. So that the presence of nonfostered street vendors on Jalan Mangga Besar does not interfere with access of pedestrians who want to use the sidewalk.
\end{abstract}

Keywords: Street Vendors; Trading Patterns; Mangga Besar; Pavement; Design

\section{PENDAHULUAN}

Trotoar umumnya digunakan atau dimanfaatkan untuk pejalan kaki. Trotoar menjadi wadah bagi pejalan kaki untuk melakukan mobilisasi dari satu tempat ke tempat lain. Fungsi utama trotoar adalah untuk memberikan pelayanan kepada pejalan kaki sehingga dapat meningkatkan kelancaraan, keamanan, dan kenyamanan pejalan kaki tersebut. Trotoar juga berfungsi memperlancar lalu lintas jalan raya karena tidak terganggu atau terpengaruh oleh lalu lintas pejalan kaki. Pejalan kaki berada pada posisi yang lemah jika bercampur dengan kendaraan, sehingga akan memperlambat arus lalu lintas. Dahulu kala, trotoar bukan hanya digunakan untuk pejalan kaki, tetapi juga digunakan untuk kuda, pedati dan gerobak. 
Saat ini trotoar dimanfaatkan pedagang kaki lima untuk berdagang, sehingga akses pejalan kaki hampir sepenuhnya hilang. Menurut Undang-Undang Nomor 22 Tahun 2009 tentang lalu lintas dan angkutan jalan, trotoar adalah salah satu fasilitas pendukung penyelenggaraan lalu lintas. Trotoar merupakan hak pejalan kaki, sama seperti tempat penyeberangan.

Keberadaan dan kelangsungan kegiatan sektor informal dalam sistem ekonomi kontemporer menurut Wauran (2012) bukanlah gejala negatif, namun lebih sebagai realitas ekonomi kerakyatan yang berperan cukup penting dalam pengembangan masyarakat dan pembangunan nasional. Setidaknya, ketika program pembangunan kurang mampu menyediakan peluang kerja bagi angkatan kerja, sektor informal dengan segala kekurangannya mampu berperan sebagai penampung dan alternatif peluang kerja bagi para pencari kerja.

Jalan Mangga Besar merupakan salah satu pusat hiburan malam di Jakarta. Kawasan ini memiliki daya tarik tersendiri sebagai tempat untuk melakukan usaha. Ada \pm 200 PKL (Warta Kota, 2015) yang berdagang berbagai jenis makanan di trotoar Jalan Mangga Besar. Keberadaan mereka hampir di sepanjang trotoar Jalan Mangga Besar. Ketika sore menjelang malam hari, pedagang kaki lima mulai bersiap mendirikan tendanya di trotoar maupun jalur lambat di Jalan Mangga Besar.

Dari latar belakang ini, dapat disimpulkan bahwa keberadaan sektor informal memberikan dampak positif dalam hal menyerap tenaga kerja yang tidak terserap di sektor formal dan membantu perekonomian negara tetapi pemanfaatan lokasi berdagangnya mengganggu lingkungan sekitar, khususnya di Jalan Mangga Besar. Sehingga peneliti tertarik untuk membahas "Pola-Pola Pemanfaatan Trotoar Oleh Pedagang Kaki Lima di Jalan Mangga Besar".

\section{LANDASAN TEORI}

\section{Kajian Pedagang Kaki Lima}

Menurut McGee dan Yeung pedagang kaki lima memiliki 3 pola (persebaran, pelayanan dan pengelolaan), yaitu:

\section{Pola Persebaran}

- Pola persebaran memanjang (linear concentration)

Pola persebaran ini dipengaruhi oleh pola jaringan jalan. Aktivitas jasa sektor informal (PKL) dengan pola persebaran memanjang terjadi di sepanjang atau pinggir jalan utama atau pada jalanjalan penghubungnya.

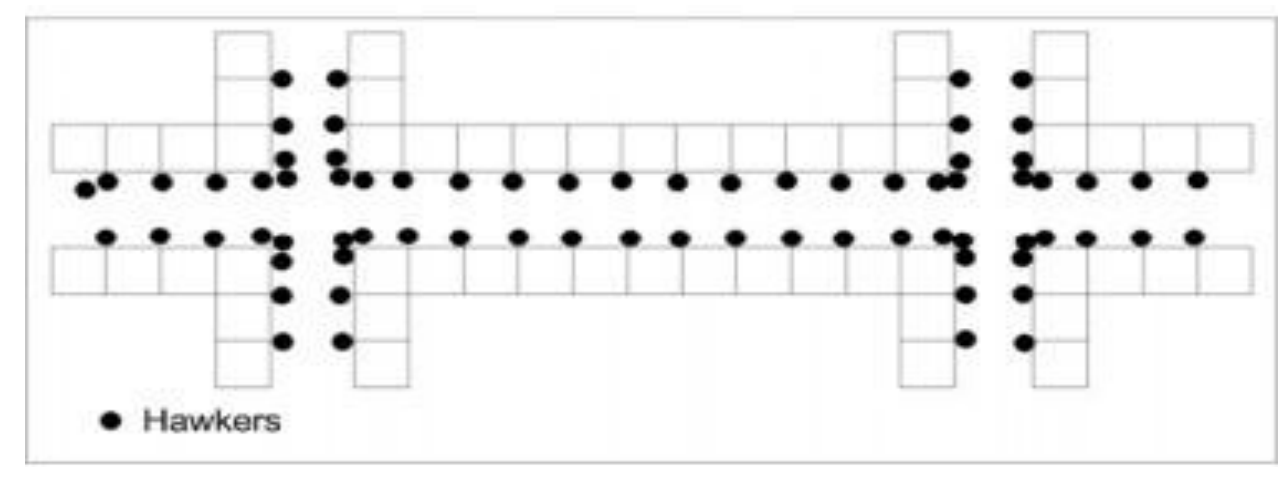

Gambar 1. Pola Persebaran Memanjang (Linier)

Sumber : McGee dan Yeung (dalam Surya, 2006) 
- Pola persebaran mengelompok (focus agglomeration)

Pola persebaran ini dijumpai pada ruang-ruang terbuka, taman, lapangan dan sebagainya.

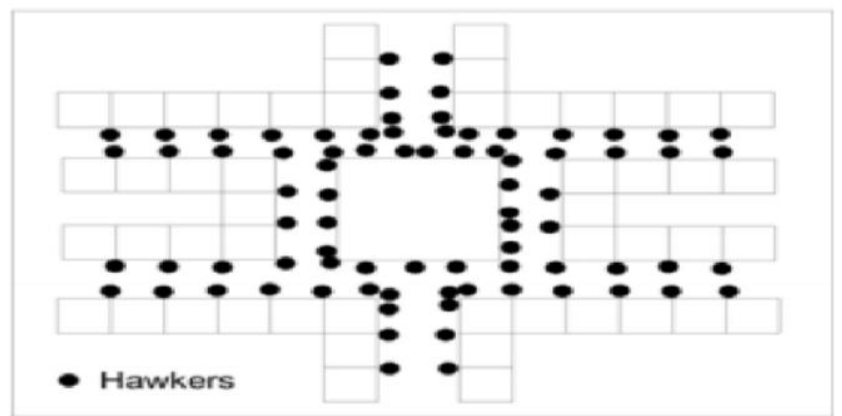

Gambar 2. Pola Persebaran Mengelompok (Focus Agglomeration) Sumber: McGee dan Yeung (dalam Surya, 2006)

\section{Pola Pelayanan}

- Unit PKL tidak menetap, Unit ini ditunjukkan oleh sarana fisik perdagangan yang mudah dibawa, atau dengan kata lain ciri utama dari unit ini adalah PKL yang berjualan bergerak dari satu tempat ke tempat lain.

- Unit PKL setengah menetap, Ciri utama unit ini adalah PKL yang pada periode tertentu menetap pada suatu lokasi kemudian bergerak setelah waktu berjualan selesai (pada sore hari atau malam hari).

- Unit PKL menetap, Ciri utama unit ini adalah PKL yang berjualan menetap pada suatu tempat tertentu.

\section{Pola Pengelolaan}

- Pengelolaan lokasional, Sektor informal diharapkan menempati lokasi yang sesuai dengan rencana penataan dari masing-masing kota.

- Pengelolaan Struktural, Pemerintah kota di kawasan Asia Tenggara berdasarkan penelitian yang dilakukan oleh McGee dan Yeung (dalam Surya, 2006) lebih sering menerapkan pola pengelolaan lokasional walaupun tidak selalu berhasil. Selain bentuk pengelolaan lokasional, pemerintah kota mencoba pola pengelolaan struktural. Adapun yang termasuk dalam pengelolaan struktural adalah perizinan, pembinaan, bantuan dan pinjaman.

\section{Ruang Publik}

Carr (1992) melihat ruang terbuka publik sebagai ruang milik bersama, tempat masyarakat melakukan aktivitas fungsional dan ritualnya dalam suatu ikatan komunitas, baik kehidupan sehari-hari maupun dalam perayaan berkala yang telah ditetapkan sebagai sesuatu yang terbuka, tempat masyarakat melakukan aktivitas pribadi dan kelompok. Ruang terbuka publik merupakan ruang wadah aktivitas sosial yang melayani dan juga mempengaruhi kehidupan masyarakat kota. Ruang terbuka juga merupakan wadah dari kegiatan fungsional maupun aktivitas ritual yang mempertemukan sekelompok masyarakat dalam rutinitas normal kehidupan sehari-hari maupun dalam kegiatan periodik.

Tetapi jika dilihat dalam arti fisik, menurut Darmawan (2007), ruang publik harus terbuka bagi siapa saja warga kota yang ingin berekspresi, apakah berkaitan dengan konten sosial, politik, ekonomi maupun kebudayaan. Sementara Puspitasari (2009) berpendapat bahwa PKL tidak mungkin dihilangkan dari kegiatan di ruang publik dan keberadaannya merupakan pelengkap dari segala unsur kehidupan publik, terutama di kawasan perdagangan. Menurut Ali Madanipur 
(2003), suatu ruang dianggap sebagai ruang publik jika dikontrol oleh pihak yang memiliki wewenang publik, berhubungan dengan kepentingan orang banyak, terbuka dan tersedia untuk orang banyak serta digunakan bersama oleh semua anggota masyarakat.

Tetapi jika dilihat dalam konteks perkotaan, ruang publik sebagaimana diungkapkan Mitchell (dalam Sharma and Konwar, 2014), merupakan tempat yang ada di kota yang diciptakan manusia, yang penting bagi manusia untuk mengartikulasikan hak-haknya.

\section{Sektor Informal}

Menurut Simanjuntak (dalam Nugroho, 2010), sektor ini telah memberi andil dan ikut berperan dalam menjawab pertanyaan-pertanyaan dasar mengenai proses pembangunan ekonomi dan perubahan sosial. Bahkan dalam situasi kelesuan ekonomi sektor informal dapat berfungsi sebagai katup pengaman. Sehingga sudah selayaknya bilamana kebijakan-kebijakan ekonomi dalam rangka pemerataan kesempatan kerja dan kesempatan berusaha pertumbuhannya dirangsang dari "bawah" khususnya yang bergerak di sektor industri kecil di pedesaan dan sektor informal di perkotaan. Tetapi menurut Keith Hart (dalam Manning dan Effendi, 1989), sektor informal adalah sebagai bagian angkatan kerja yang tidak terorganisir.

Di dalam teori Dual Labour Market yang diungkapkan oleh Saint Paul (dalam Tunas, 2008), sektor informal merangkul orang yang tidak bisa masuk pasar primer dan sekunder. Di sisi lain Castells dan Portes (dalam Haris, 2011) mengajukan definisi sektor informal sebagai proses perolehan penghasilan diluar sistem regulasi. Istilah ini merupakan suatu ide akal sehat (common sense notion) yang karena batas-batas sosialnya terus bergeser, tidak dapat dipahami dengan definisi yang ketat. Mereka melihat bahwa sektor informal sebagai suatu proses perolehan penghasilan mempunyai ciri-ciri sentral yaitu tidak diatur oleh lembaga-lembaga sosial dalam suatu lingkungan legal dan sosial. Menurut mereka batas-batas ekonomi informal bervariasi secara substansial sesuai dengan konteks dan kondisi historisnya masing-masing.

\section{METODE PENELITIAN}

Penelitian ini menggunakan pendekatan induktif, yaitu langsung pengamatan ke lapangan yang berada di Jalan Mangga Besar. Selain melakukan pengamatan langsung di lapangan, penulis juga melakukan wawancara dengan pedagang kaki lima di Jalan Mangga Besar dan staff kelurahan di Mangga Besar.Pengelolaan data yang diperoleh yaitu dari bacaan jurnal sejenis dan isu terbaru mengenai pemanfaatan trotoar oleh pedagang kaki lima digabungkan dengan hasil wawancara yang didapat dari pedagang kaki lima dan staff kelurahan.

\section{PEMETAAN AWAL: MUNCULNYA PKL DI JALAN MANGGA BESAR}

Mangga Besar merupakan salah satu daerah konsentrasi penduduk Cina pada abad ke-19 bersama dengan Glodok dan Pinangsia. Maka dari itu Mangga Besar merupakan salah satu tempat berdagang penduduk Cina. Berdasarkan buku karya Firman Lubis yang berjudul "Jakarta 1950-1970", pada masa itu terdapat tempat hiburan khas penduduk Cina di Prinsen Park, yang kemudian berubah menjadi Taman Hiburan Rakyat Lokasari. Suasananya kental dengan tradisi budaya Cina, baik toko-tokonya, restoran, bioskop, gedung sandiwara, bau hio, dan lain-lain. Sampai akhirnya pada tahun 1950-an akhir penduduk Cina mulai dipaksa melebur dengan pribumi.

Menurut buku itu pula pada tahun 1960-an, saat Gubernur Ali Sadikin menjadi Gubernur Jakarta, dibuatlah rencana jangka panjang atau master plan pembangunan Jakarta 1965-1985. Beliau membuat banyak sekali pembangunan dan perubahan di kota Jakarta. Ia pun dikenal sebagai 
pemimpin yang kuat, keras, dan tegas. Salah satu tindakannya adalah berani melakukan pelebaran jalan-jalan dengan memotong pekarangan rumah, toko atau kantor.

Selepas pemerintahan Gubernur Ali Sadikin, Gubernur berikutnya kurang mempunyai keberanian dan ketegasan dalam membenahi Jakarta yang tumbuh dengan sangat pesat seperti penyakit kanker. Mereka lebih senang cari aman. Kurang punya nyali untuk menindak dan mengatur penyerobotan tanah, penggunaan trotoar oleh pedagang kaki lima, percaloan berbagai urusan, pengalihan daerah hijau, pembangunan liar, dan lain-lain. Hal tersebut senada dengan Merdeka (20/09/2012), setelah pemerintahan Ali sadikin, Tjokropranolo yang memimpin Jakarta. Pada masa pemerintahannya, menaruh perhatian besar kepada pedagang kaki lima, sayangnya perhatian tersebut menimbulkan efek samping, yaitu kemacetan lalu lintas dan kesemrawutan transportasi kota menjadi masalah yang sulit dipecahkan. Perda yang mengatur pedagang tidak berjalan efektif, sehingga mereka masih berdagang di wilayah terlarang, menempati badan jalan, dan memacetkan lalu lintas.

Jalan Mangga Besar sebenarnya terbagi ke dalam dua wilayah, yakni Jakarta Pusat dan Jakarta Barat, yang dipotong oleh Rel Kereta Api dan stasiun Mangga Besar. Daerah yang ramai ada di Jalan Mangga Besar wilayah Jakarta Barat yang pusatnya adalah Taman Hiburan Rakyat Lokasari (dahulu Prinzen Park). Memasuki sore hari, PKL (Pedagang Kaki Lima) menempati trotoar maupun jalur lambat di kedua sisi jalan yang sudah berlangsung sejak tahun 1970-an menurut Betawikite (04/04/2016). Memasuki tahun 1990an menurut Kompas (12/04/2013), Lokasari di daerah Mangga Besar menjadi kawasan tempat hiburan dan restoran yang kembali nyaris tak pernah tidur.

\section{HASIL PENELITIAN DAN PEMBAHASAN: PKL DI JALAN MANGGA BESAR Pkl Non Binaan vs Pkl Binaan}

PKL non binaan ini sudah ada sejak dahulu. Mereka sebagian besar berasal dari luar Jakarta. Mereka berdagang makanan, obat, buah, koran dan majalah. Mereka tidak dapat menyewa kepada pihak kelurahan ataupun instansi pemerintah terkait untuk memanfaatkan trotoar ataupun bahu jalan untuk berdagang. Ada sebagian pedagang kaki lima meminta izin untuk berdagang kepada kelurahan ataupun RW setempat. Lalu mereka meminta izin dan menyewa lapak kepada juru parkir setempat di lokasi yang diinginkan oleh pedagang kaki lima tersebut. Ada juga sebagian pedagang kaki lima langsung menempati trotoar ataupun bahu jalan yang tidak dikuasai oleh tukang parkir. Mereka datang dan langsung mendirikan tenda dagangan ataupun menaruh gerobak dagangan mereka dan berdagang di sana. Sehingga pedagang kaki lima ini berdagang tanpa membayar sewa ataupun retribusi. 


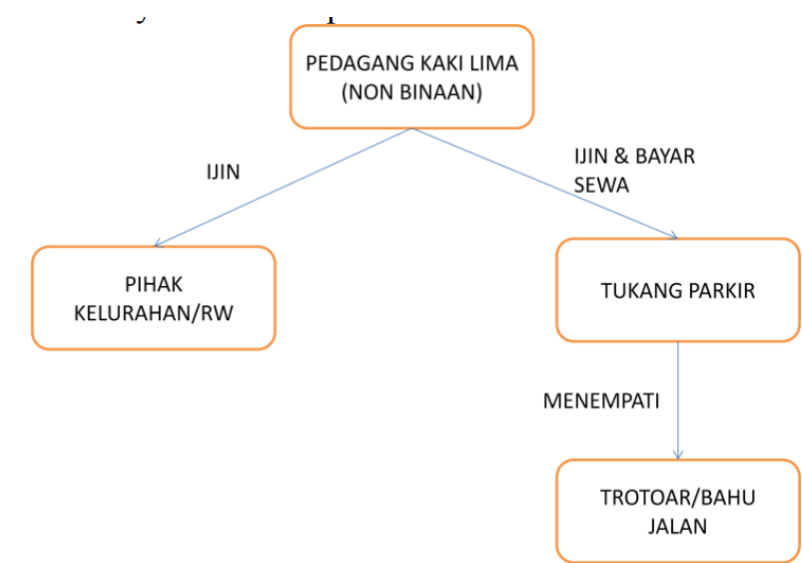

Gambar 3. Proses PKL Non Binaan Mendapatkan Lokasi Berdagang Sumber: Observasi Lapangan, Maret 2018

PKL binaan merupakan pedagang kaki lima yang resmi, karena mereka terdaftar di dinas UMKM maupun kelurahan sebagai PKL binaan. Program PKL binaan ini resminya adalah pada tahun 2016. Pedagang kaki lima yang ingin dibina dan menjadi binaan nantinya memiliki kewajiban membayar retribusi setiap bulannya. Pembayaran dilakukan menggunakan rekening Bank DKI. Dinas UMKM belum akan menjadikan seluruh pedagang kaki lima menjadi binaan, karena lokasi yang dapat dijadikan loksem (Lokasi Sementara) bagi pedagang kaki lima tidaklah banyak.

Tabel 1. Jumlah PKL Binaan Kecamatan Taman Sari

\begin{tabular}{|c|c|c|c|c|c|c|c|c|}
\hline \multirow[t]{2}{*}{ No } & \multirow[t]{2}{*}{$\begin{array}{c}\text { KECA } \\
\text { MATAN } \\
\end{array}$} & \multirow[t]{2}{*}{$\begin{array}{c}\text { KELU } \\
\text { RAHAN }\end{array}$} & \multirow[t]{2}{*}{$\begin{array}{c}\text { KODE } \\
\text { LOKSEM }\end{array}$} & \multirow[t]{2}{*}{ ALAMAT (JALAN) } & \multicolumn{2}{|c|}{ JUMLAH } & \multirow[t]{2}{*}{$\begin{array}{c}\text { JENIS } \\
\text { DAGANGAN } \\
\end{array}$} & \multirow[t]{2}{*}{$\begin{array}{l}\text { WAKTU } \\
\text { USAHA } \\
\end{array}$} \\
\hline & & & & & KIOS & PEDAGANG & & \\
\hline 1 & Tamansari & $\begin{array}{c}\text { Mangga } \\
\text { Besar }\end{array}$ & 02.04 .03 .26 & JL. Mangga Besar I & 22 & 22 & Kuliner & $17.00-24.00$ \\
\hline 2 & Tamansari & Maphar & 02.04 .06 .26 & JL. Kebon Jeruk VIII & 23 & 23 & $\begin{array}{c}\text { Kuliner, } \\
\text { Counter HP }\end{array}$ & $12.00-23.00$ \\
\hline
\end{tabular}

2018

Keberadaan PKL binaan terdapat di luar Jalan Mangga Besar tetapi masih berada dalam ruang lingkup Kecamatan Taman Sari. Keberadaannya terdapat di Kelurahan Mangga Besar sebanyak 22 kios dan 22 pedagang dan Kelurahan Maphar sebanyak 23 kios dan 23 pedagang. Untuk wilayah kelurahan Tangki dan Taman Sari belum terdapat pedagang kaki lima binaan

\section{Pola Migrasi dan Keterampilan PKL di Jalan Mangga Besar}

Kehadiran pedagang kaki lima di kota Jakarta memang selalu disudutkan pada posisi yang negatif, yaitu mengganggu ketertiban, pencemaran lingkungan, keindahan kota, menyebabkan kemacetan lalu lintas di sekitarnya. Kehadiran pedagang kaki lima tidak selalu dapat digambarkan secara negatif, terdapat gambaran positif dari kehadiran pedagang kaki lima, karena sebenarnya mereka merupakan sektor informal yang menggerakkan perekonomian masyarakat kota tersebut, yang hampir dapat ditemukan di setiap sudut kota besar.

Kehadiran Pedagang kaki lima di Mangga Besar bukanlah cerita baru. Kehadiran mereka sudah ada sejak lama menurut Betawikite (04/04/2016). Pedagang kaki lima ini sebagian besar merupakan pendatang yang sudah lama datang ke Jakarta untuk mencari penghasilan yang lebih baik dari di daerah asalnya dan juga untuk menghidupi keluarganya yang ada di daerah. 
Sudiarto (52 tahun) yang berdagang kaki lima sate dan soto kambing di Jalan Mangga Besar, juga merupakan pendatang yang sudah lama di Jakarta. Sebelum mempunyai usaha sendiri, beliau sudah beberapa kali bekerja dengan orang lain. Sehingga beliau sudah memiliki bekal pengetahuan dan keterampilan pada saat membuka usaha kaki lima sendiri

Senada dengan tulisan Alimi (2004), kondisi perkotaan di Indonesia, seperti juga perkotaan di negara-negara lain, banyak dijumpai pedagang kaki lima (PKL) sebagai akibat tidak mampunya pemerintah mengatasi masalah migrasi, pengangguran dan kemiskinan. Masalah migrasi ke kota terjadi karena kondisi pedesaan yang belum bisa menopang perekonomian masyarakat desa.

\section{Pola Persebaran Pkl Di Jalan Mangga Besar}

Pedagang kaki lima non binaan atau yang tidak resmi di Jalan Mangga Besar ini memiliki pola persebaran memanjang (linear concentration). Mereka berdagang mengisi trotoar dan bahu jalan yang ada. Ketika sore hari sekitar pukul lima sore, di kedua sisi jalan di Mangga Besar akan ada banyak pedagang kaki lima yang sedang mendirikan tiang-tiang penyangga, menebarkan tendanya, memotong daging, ataupun merapikan tempat dagangannya yang akan menjadi pemandangan tersendiri bagi yang sedang melewati daerah tersebut.

Pedagang kaki lima di Jalan Mangga Besar yang berada di dalam ruang lingkup kelurahan Mangga Besar, dibuka oleh pedagang nasi goreng yang berada di depan gedung kantor Dwidaya. Selepas pedagang nasi goreng ini, kehadiran pedagang kaki lima baru terlihat di depan hotel Amaris Mangga Besar. Ini dikarenakan jalan masuk utama ke Mangga Besar dari Olimo tidak lebar dan dipergunakan untuk parkir restoran yang buka 24 jam dan secara vertikal memarkir kendaraannya. Selanjutnya keberadaan PKL baru ada di depan hotel Amaris sampai dengan pinggir kali yang merupakan perbatasan antara Kelurahan Mangga Besar dengan Kelurahan Tangki. Tenda-tenda yang terlihat memanjang mengikuti panjangnya trotoar dan bahu jalan di sisi jalur lambat.

Memasuki Jalan Mangga Besar yang berada di kelurahan Tangki, kehadiran pedagang kaki lima terlihat semakin banyak. Kehadiran mereka terlihat di sepanjang trotoar dan bahu jalan yang panjang mengikuti arah jalan. Mereka berdagang bakmi, soto, sate, martabak, durian, pecel. Di sisi jalan ini terlihat berkumpulnya pedagang martabak yang ada di depan gedung Taman Hiburan Rakyat (THR) Lokasari yang begitu ramai memasuki malam hari karena hiburan malamnya. Mereka masih menjual martabaknya secara tradisional yang terlihat dari penggunaan gerobak dan menunya.

Sisi jalan lain yang mengarah ke Olimo yaitu yang berada di ruang lingkup Kelurahan Taman Sari, sangat mencolok dengan keberadaan pedagang durian yang berdekatan satu dengan yang lainnya di sepanjang jalan. Di sini pengunjung bisa langsung makan di tempat karena pedagang memanfaatkan trotoar dan bahu jalan untuk tempat duduk pengunjung.

\section{Pola Pelayanan PKL di Jalan Mangga Besar}

Pedagang kaki lima di Jalan Mangga Besar ini hampir seluruhnya adalah pedagang kaki lima yang hanya menetap di satu lokasi dan tidak berpindah ke tempat lain. Mereka membuka dagangan mereka dari sore sampai malam hari tanpa berpindah dan hanya menunggu pengunjung datang. Seperti Fahri (24 tahun) yang berdagang Es Garut yang menurutnya ayahnya selalu berdagang di satu lokasi dan tidak berpindah karena lokasinya yang sudah di beli dari kelurahan. 
Adapun pedagang kaki lima di Jalan Mangga Besar yang memiliki pola pelayanan setengah menetap. Pola setengah menetap ini adalah pedagang kaki lima yang akan berpindah ke lokasi lain setelah waktunya selesai. Biasanya hanya beberapa jam menetap di satu lokasi lalu berpindah ke lokasi lain, salah satunya adalah Sobri (62 tahun) pedagang bakpao yang menggunakan sepeda untuk memudahkannya berkeliling.

\section{Pola Pengelolaan PKL di Jalan Mangga Besar}

Pedagang kaki lima yang berdagang di Jalan Mangga Besar menggunakan / memanfaatkan trotoar maupun bahu jalan di jalur lambat kedua sisi jalan tanpa ada izin yang benar-benar resmi. Sebagian besar pedagang kaki lima langsung pada saat pertama kali datang ke lokasi langsung menempati tanpa meminta izin kepada instansi terkait selama bertahun-tahun. Mereka berdiri sendiri di dalam pengelolaan kaki limanya. Tidak ada yang mengkoordinir mereka dalam berdagang. Mereka berdagang dengan motivasi masing-masing.

Pemerintah sudah menghimbau kepada pedagang kaki lima di Jalan Mangga Besar ini apabila mereka memanfaatkan trotoar maupun bahu jalan yang merupakan fasilitas umum untuk aktivitas berdagang sehari-hari. Mereka harus mematuhi aturan-aturan yang ada, seperti mengikuti jam berdagang yang sudah ditentukan yaitu dari jam enam sore sampai jam dua belas malam, harus menjaga kebersihan lokasi berdagang.

Pengelolaan pedagang kaki lima oleh pemerintah berupa binaan dalam bentuk kontrol atau pengecekan yang dilakukan oleh pihak kelurahan dan juga dinas UMKM (Usaha Mikro Kecil \& Menengah). Pembayaran retribusi menurut Tempo (13/04/2018), retribusi yang dibayarkan oleh pedagang kaki lima binaan ini untuk menambah fasilitas di sekitar loksem (lokasi sementara). Fasilitas itu berupa fasilitas kebersihan, keamanan, dan promosi. Sehingga menurut Kompas (03/09/2014) dengan cara demikian pedagang kaki lima tidak merasa dimusuhi serta bisa lebih mudah ditata dan diawasi dan diharapkan menjaga kebersihan lokasi jualan dan pedagang kaki lima menyambut baik rencana Pemerintah Provinsi DKI Jakarta melegalkan aktivitas jual-beli mereka. Adanya ketentuan dan persyaratan tertentu juga tidak dianggap memberatkan.

\section{Kelembagaan Bawah Tanah Mangga Besar}

Jika kita lihat sekilas pedagang kaki lima di Jalan Mangga Besar berdagang dengan keadaan yang resmi, tetapi sebenarnya lokasi berdagang pedagang kaki lima sebagian disewa melalui juru parkir. Apabila lokasi tersebut bukan untuk parkir, pedagang dapat langsung masuk tanpa harus membayar sewa. Jika lokasi tersebut untuk parkir, pedagang harus membayar sewa kepada juru parkir berkisar sepuluh sampai lima belas ribu rupiah sehari (garis putus-putus warna merah).

Juru parkir mengenakan biaya sewa berkisar sepuluh sampai lima belas ribu rupiah per hari dengan alasan untuk menutupi setoran ke dinas perparkiran sebesar dua puluh ribu rupiah. Sehingga menimbulkan indikasi sisa uang yang diperoleh oleh juru parkir di Jalan Mangga Besar, apakah disimpan sendiri atau mengalir ke pihak lain (garis putus-putus warna hijau). Inilah yang dikatakan sebagai skema menutup mata, adanya indikasi oleh oknum RT/RW/kelurahan yang membiarkan pedagang kaki lima berdagang di fasilitas umum dengan cara sewa trotoar dan bahu jalan kepada juru parkir (garis putus-putus warna ungu). Skema ini sudah berjalan bertahun-tahun, dan sudah seperti hal yang biasa dan tidak menjadi masalah bagi masyarakat sekitar Mangga Besar, karena mereka sendiri menikmati kehadiran pedagang kaki lima, sehingga tidak memperdulikan bagaimana proses pedagang ini ada di trotoar dan bahu jalan. Hal ini merupakan enacted institution, proses melembaga yang dengan sengaja dilakukan 
untuk memenuhi kebutuhan pedagang dan juga pihak-pihak terkait seperti juru parkir di Mangga Besar.

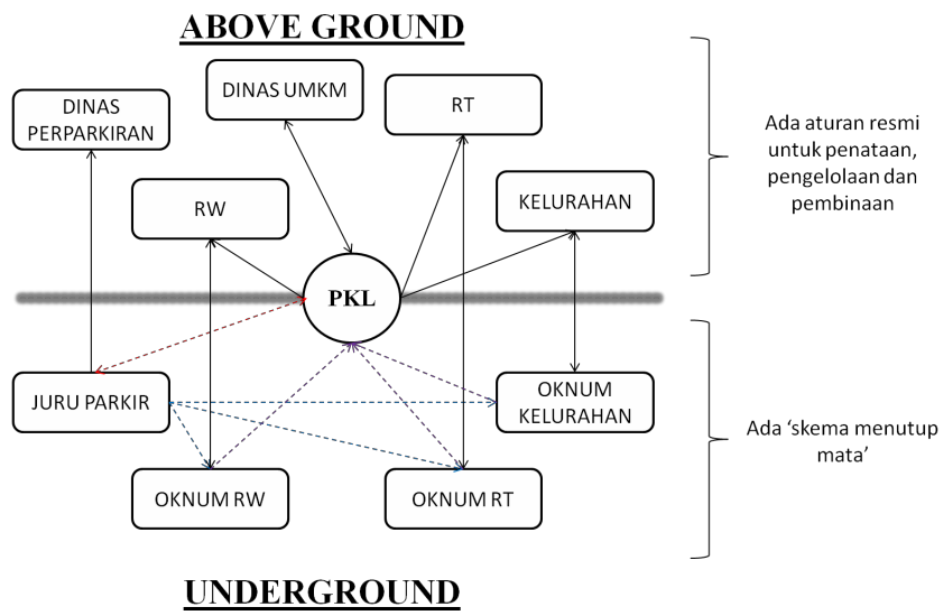

Gambar 4. Skema Pedagang Kaki Lima Antara yang Terlihat Dengan yang Tidak Terlihat Sumber: Hasil observasi dan wawancara

Pihak kelurahan dan juru parkir di Mangga Besar memiliki andil besar terhadap keberadaan pedagang kaki lima. Mereka yang datang meminta ijin kepada pihak RT/RW/kelurahan dibiarkan begitu saja berdagang walaupun sebenarnya trotoar dan jalur lambat bukan merupakan area berdagang. Juru parkir pun yang bertugas untuk membantu kendaraan- kendaraan yang akan parkir di kawasan ini, turut menyumbang andil hadirnya pedagang kaki lima, pedagang kaki lima dapat menyewa lokasi dagang di atas trotoar ataupun bahu jalan di jalur lambat kepada juru parkir

\section{KESIMPULAN}

Pola persebaran pedagang kaki lima di Jalan Mangga Besar berbentuk memanjang, sesuai dengan yang dikemukakan oleh McGee dan Yeung (dalam Surya, 2006) pola ini banyak menjadi pilihan pedagang kaki lima karena aksesibilitas yang tinggi sehingga berpotensi besar untuk mendatangkan konsumen.

Pedagang kaki lima di Jalan Mangga Besar memiliki pola pelayanan menetap dan setengah menetap. Seperti yang dibahas oleh McGee dan Yeung (dalam Widjajanti, 2009), pola ini merupakan kecerdikan pedagang kaki lima melihat potensi suatu lokasi. Pedagang kaki lima yang menetap, mereka sudah memiliki lokasi dagang yang biasanya melalui aktivitas sewa dengan juru parkir. Juru parkir akan mengenakan biaya sewa sebesar sepuluh sampai lima belas ribu rupiah dalam sehari. Sehingga pedagang kaki lima akan bersifat menetap di satu lokasi saja. Pedagang kaki lima yang setengah menetap, mereka tidak terikat pada sewa lokasi berdagang mereka. Mereka akan berdagang dalam jangka waktu tertentu lalu berpindah ke lokasi lain. Bentuk ruang yang nyaman juga akan memberikan pengaruh lamanya waktu pedagang kaki lima menetap.

Pedagang kaki lima di Jalan Mangga Besar seluruhnya adalah pedagang kaki lima non binaan dan berdagang di atas trotoar yang merupakan akses pejalan kaki dan bahu jalan yang merupakan jalur lalu lintas kendaraan. Pemerintah masih mengizinkan mereka berdagang dengan syarat pengaturan waktu berdagang. Waktu berdagang ditentukan dari jam enam sore sampai dengan tengah malam. Tetapi di lapangan, masih banyak pedagang yang tidak sesuai waktu dan melewati batas waktu berdagang. 


\section{REKOMENDASI}

Setelah menjabarkan kesimpulan yang diperoleh dari penelitian ini, peneliti juga akan memberikan rekomendasi bagi bidang pendidikan dan juga pemerintah, sebagai berikut:

a. Bagi bidang pendidikan, peneliti merekomendasikan sebagai berikut:

a) Dapat lebih didalami lagi persoalan mengenai aktivitas non resmi yang ada pada dunia antara pedagang kaki lima dengan penyewa lokasi berdagang, terkait sewa dan juga uang sewa nya.

b) Membantu pemerintah dalam hal membuat perencanaan kota mengenai lokasi berdagang kaki lima agar tidak mengganggu pejalan kaki dan lalu lintas.

b. Bagi bidang pemerintah, peneliti merekomendasikan sebagai berikut:

c) Perubahan desain trotoar karena melihat kejadian di lapangan, banyak trotoar yang dibiarkan menjadi aktivitas berdagang kaki lima, lebih baik pemerintah merubah desain trotoar tersebut dengan dua jalur yang memiliki lebar cukup dan terpisah untuk pejalan kaki dan pedagang kaki lima, agar tidak merugikan salah satu pihak.

d) Perlu adanya kontrol dan pengawasan sebagai tindak lanjut dibuatnya peraturan informal. Tanpa ada tindak lanjut tersebut, peraturan tersebut tidak bermanfaat.

\section{DAFTAR PUSTAKA}

Betawikiteblog. (2016). Kondisi di Jakarta, Mangga Besar Raya. https://betawikiteblog. wordpress.com/2016/04/04/mangga-besar-raya/

Carr, Stephen, et all. (1992). Public Space. USA: Cambridge University Press.

Darmawan, Edy. (2007). Peranan Ruang Publik dalam Perancangan Kota (Urban Desain). Pidato Pengukuhan Guru Besar pada Upacara Penerimaan Jabatan Guru Besar dalam Ilmu Arsitektur. Semarang: Fakultas Teknik Universitas Diponegoro.

Haris, D Muhammad. (2011). Strategi Pengembangan Usaha Sektor Informal Dalam Mendukung Pertumbuhan Ekonomi Dan Penanggulangan Kemiskinan Di Perkotaan. Serang: Prodi Administrasi Negara FISIP Universitas Sultan Ageng Tirtayasa.

Kawarazuka. N, Bene, C, Prain, G. (2017). Adapting To A New Urbanizing Environment: Gendered Strategies Of Hanoi's Street Food Vendors. International Institute for Environment and Development (IIED). Volume 30 (1), page 233 - 248.

Lubis, F. (2018). Jakarta 1950 - 1970. Cetakan Pertama (Edisi Kompilasi), Masup Jakarta. Manning, Cris dan Tajuddin Noer. (1989). Urbanisasi, Pengangguran dan Sektor Informal di Kota. Jakarta: Gramedia.

Nugroho, Fajar A. (2010). Penataan Sektor Informal Di Belakang Kampus UNS Studi Kasus Dampak Ekonomi Pada Pedagang Di Pasar Panggungrejo Jebres, Surakarta. Surakarta: Fakultas Keguruan dan Ilmu Pendidikan Universitas Sebelas Maret.

Pribadi, Max Agung. (2015). Tanggulangi Kemacetan, PKL di Taman Sari

Ditata. http://wartakota.tribunnews.com/2015/03/28/tanggulangi-kemacetan-pkl-ditaman-sari- ditata.

Puspitasari, A Wulan. (2010). Analisis Faktor-Faktor Yang Mempengaruhi Minat Migrasi Sirkuler Ke Kabupaten Semarang. Semarang: Universitas Diponegoro.

Sari, H Rachma. (2012). Jejak Langkah dan Karya 13 Gubernur Jakarta. https://www.merdeka.com/peristiwa/jejak-langkah-dan-karya-13-gubernur-jakarta.html

Surya, Octora L. (2006). Kajian Karakteristik Berlokasi Pedagang Kaki Lima Di Kawasan Sekitar Fasilitas Kesehatan. Semarang: Fakultas Teknik Universitas Diponegoro.

Tunas, D. (2008). The Spatial Economy In The Urban Informal Settlement. Faculteit Sociale Wetenschappen, Katholieke Universiteit Leuven. 
Wauran, Patrick C. (2012). Strategi Pemberdayaan Sektor Informal Perkotaan Di Manado. Fakultas Ekonomi Universitas Sam Ratulangi. 
